\title{
FAMILY PLANNING IN PAKISTAN: A SITE OF CONFRONTATION IN ISLAM
}

\author{
Muhammad Sadiq \\ PhD Scholar, \\ Department of Sociology and Criminology, University of Sargodha \\ sadiq.vaence@gmail.com \\ Dr. Yasir Nawaz Manj \\ Associate Professor/Chairman, Department of Sociology and Criminology, \\ University of Sargodha, Sargodha \\ yasir.nawaz@uos.edu.pk \\ Naveed Iftikhar \\ Director Development, Planning and Development Department \\ Government of Punjab
}

\begin{abstract}
Population explosion is one of the serious social issues that has direct effect on the prosperity of any nation in the world. For maintenance balance between population and resources, various countries, mostly, developed have formulated family planning programs. As Pakistan's population has surpassed 225 million, the country's family planning policy has been unable to substantially boost contraceptive use. This study has tended to focus on service and awareness delivery failures, 'religious, cultural' hurdles, and variable political backing to analyses the hurdles. The first approach is to raise awareness about the health concerns of multiple pregnancies in a short period. Women who are more aware of the reduced health risks associated with spacing children are more likely to begin utilizing contraception. It is critical to target men as well as women while doing awareness-raising initiatives.
\end{abstract}

Keywords: Birth control, Islam, Discourse site, Protest, Religious leaders, Consciousness

\section{INTRODUCTION}

In 2012, Pakistan is the world's 6th most heavily populated country with an approximate population of 225 million (World Population Review, 2021). Even though Pakistan established commercial family planning program in 1953 and state-run programs in the 1960s (Corsa, 1965), the Contraceptive Prevalence Rate improved by just one-fourth percent per year until 1990. The CPR hiked dramatically, from $12 \%$ in last decade of twentieth century to $33 \%$ in first year of twenty-first century, with most of the rise in countryside areas and employing conventional practices.

Over next generation, the Contraceptive Prevalence Rate plummeted back to $30 \%$ in 2006-7, with 17 million married pregnant women (MWRA) not using any Family Planning, containing around six million who have an incomplete need for Family Planning, and 3 lacs to 8.5 lacs females seeking miscarriages each year, often as a Family Planning approach. There is a doctrine much of the success of the 1990s, though spurred in part by the establishment of public sector outreach FP programs like as the Dame Health Professionals program, was because of non-religious movements and occurred despite, instead of, the facilities extended. The bulk of FP services, like much of health care, have transferred from the government to private organizations in the last decade. The state sector Government agencies of Health and Population Welfare now offer thirty-five percent of Family Planning system in state, while the corporate market now offers most FP services nationwide, with women/couples generally self-procuring supplies from market or services from private clinics or Non-Governmental Organization.

The prominence of FP methods considering Islamic teachings needs long been a matter of debate. 
The subject has been investigated from a few angles, including intellectual and academic concerns. However, very few empirical studies on this topic are ever conducted to indicate the actual condition at the public stage. In Pakistan, antenatal care program was established in the 1950s, with varying degrees of support from the government, sponsors, and the general public. The concept and practices of family planning have long been a source of contention, particularly from an Islamic standpoint. It is worth mentioning that religious experts from various Islamic sects have frequently expressed opposing views to subject \& approval of measures in the field of FP. That's also crucial note, community-level contraceptives techniques and their relation to Islamic teachings are always lacking in firsthand proofs. Keep one going, it was necessary undertaking realistic study that was as close to reality as feasible, and some might stumble by many accounts, anecdotes, and also mythologies about the role of teachings of Islam to prevent or enable FP techniques.

Many different structured family planning programs across the world that provide contemporary contraception and accompanying services, which have grown more prevalent in the last 40 years. These projects seek to promote women's and children's health and to limit inhabitant's growth in nations where high occupants increase is considered as a hindrance to socioeconomic progress. The United Nations International Conference on Population and Development (ICPD) in 1994 and the Millennium Development Summit (MDS) in 2000 both urged for universal approach to contraceptive information and assistances. Religious nations who participated in the ICPD typically supported the conference's Program of Action by caveat by assuming and implementing its suggestions in conformity with Islamic Teachings, a location required for Islamic Nations grabbing the summit suggestions home for execution. The International Conference on Population and Development's System of Act focuses on human being flourishing along with providing a comprehensive structure to decreasing occupants increase \& making better education. The Program's social messaging is universal approach to a broad safety range and dependable contraceptive options.

The attitude of Islam on FP \& conditions below it may be practiced has an immediate effect on how Islamic nations may fulfil their progress objectives. The International Conference on Population and Development Program of Action noted that implementing their guidelines are an autonomous prerogative of every state, compatible by federal rules \& policy objectives, with full regard for its people's diverse religious and ethical beliefs and cultural backgrounds, and in accordance with internationally recognized "international human rights" (UNFPA,1994). The prevalent attitudes and practices are frequently tied to Islamic beliefs, and the same is true for family planning techniques. Although family planning information is now practically ubiquitous in Pakistan, there is still a gap between knowledge along with practical. It has been noticed that Islam is one of the reasons given by people for not using family controlling techniques. We all know that in a culture for instance Pakistan, where academics is scarce as well as the bulk of individuals hold conservative views, religious leaders wield enormous power over the populace. In the framework of Islamic teachings, a Muslim has 3 sources of knowledge from which one can find answers to inquiries about various elements of human existence. These sources are: Al Quran; $\mathrm{Al}$ Hadith and Sunnah of Hazrat Muhammad (PBUH). The opinions of advisers of jural school competent to elucidate Islamic principles; hence, Muslim seek out advice in any angle.

There are 2 major sects in Pakistan: Shia \& Sunni, with the Sunni ideology dominating. Leaders in both sects inspire their admirers in another manner, but they also have problems. Because contemporary science and ideas are rarely taught in conventional and religious institutions, the majority of them are unaware of current events. As a result, religious disputes and disagreements exist among distinct communities. A single holy man of any sect is not satisfactory to all Pakistani Muslims. Pakistani occupants routinely connect with divine leaders to solve their concerns; the most essential components is religious gatherings where people may communicate with each other and. Namaz is amongst the most significant occasions. The sheikh mosque conducts the prayers five times a day and serves as the organization's spiritual head; no religious ceremonies may be done without his permission. In some ways, he seems to be the most accessible a communal religious figure, and the individuals share their difficulties as well as difficulties with him both among themselves. Because most inhabitants in Pakistan have blind confidence in religious leaders, they may perform a critical role in upbringing about behavioral change 
among the group of people for their societal prosperity, especially in delicate issues such as family planning.

To strengthen the population welfare program, a coordinated strategic approach including all those who really important in Pakistan, especially traditional religious leaders, is required. The initiative can reach out to more conservative populations by incorporating religious leaders. The Prophet's (PBUH) sayings supported the idea of preventing conception, allowing some of his admirers to engage in 'azl'. These hadith provided Muslims' initial inducive legal reasoning on contraception, \& they were important arguing weapons in future Moral jurisprudence on contraception. As the religion of intact nature, Islam has never been hostile to what is beneficial for individual. In fact, it has always been ahead in the quest to attain this good, until it comes into contradictions with the intentions of the law giver. Contraception, as characterized by Islamic lessons, is neither diverse to marriage or childbearing, nor does it thought involve forswearing in the conventions of predetermination organization, for master put reason upon people to engage him to separate between the gainful along with the harmful, just as to help him in after the manner that would get delight in the current day and the following day.

Contraception is regarded permissible in Islam, though on the question of birth control, its legality, the criteria for practice, and the techniques that may be used, Muslim justice does not speak in unison. It is thought that coition interruptions were authorized (mubah), and that this authorization may be affirmed using experimental tactics. In general, it had been noticed that couple hundred million of rupees been used through inter-state and overseas organizations to promote contraceptive activities in the country; therefore, an assumption that misunderstanding regarding how Islam regards FP is a major impediment for widespread adoption of FP programs. Many Muslims Religious academics have misconceptions regarding FP in the perspective of Islamic teachings. Nonetheless, owing to the susceptivity of the matter as well as the fear of condemnation of Islam, no national stage qualitative ever in-depth investigation in Pakistan has been conducted. It is often assumed that divine authorities do not openly support occupant's welfare programs such as contraceptive, which is why population programs in Pakistan have not produced the intended outcomes when compared to other Muslim nations.

Ignorance, misunderstandings, and a lack of sufficient knowledge may be the root causes of opposition to family planning. A major hurdle to the use of contraceptives in the nation is a lack of awareness about Islam and modern contraceptives. Taking a gander at this trouble, it is important to have a reflexive stance of the current circumstance just as recognize that the two sides who participate in the execution of the preventative arranging, a) the ones who are the objectives of approaches and b) the ones who devise and execute arrangements - are in lopsided force positions. It was too critical to conduct an experiment, which is required and regarded necessary to evaluate people's and religious leaders' opinions and views, as well as their knowledge and views on family planning.

\section{Research Objectives}

The essential objectives of this investigation are to comprehend the present status of information about Islam and family arranging as a rule, just as to assemble data fair and square of mindfulness and mentalities of Religious masters in regard to Islam and family arranging. To learn about the current role of religious Scholars in delivering FP information to particular societies.

\section{Current Scenario}

Before delving into the conceptual elements that surround the study issue, it is fair to look at certain demographic aspects linked to the Muslim community, which will aid in understanding the topics offered in this research report. According to data, the distribution of Muslims in the seven areas changed somewhat between 1988 and 2008. Central Asia, South Asia, and South-East Asia dropped around two standard deviations, while Sub-Saharan Africa rose from 14-19\% and America and Europe climbed from $1-2 \%$. Pew Research Center. As indicated by the discoveries, by the center of 2009 , there were about 1.57 billion Muslims living everywhere on the globe, addressing $23 \%$ of an expected 2009 total populace of 6.8 billion, an ascent from 19\% in 1988. India has the world's third-biggest Muslim populace. China has a greater number of Muslims than a few Bedouin nations, whereas Russian Republic has more 
Muslims than Lebanon and Jordan.

\section{Dynamics of Family Planning}

Family planning is simply described as "a programme to restrict the number and spacing of children in a family via the use of contraception or other means of birth control" (Butler \& Clayton, 2009). Millions of individuals benefit from family planning programmes, which provide reproductive health care that saves lives, prevents unplanned births, and provides additional options. Family planning initiatives require a strong commitment and appropriate money to ensure universal approach to high-standard fertile medical care.

Health-care personnel support, policymakers, patron organizations, female's groups, news media, religious leaders as well as community leaders is likewise critical. Family planning influences varies throughout civilizations, ranging from profit-making, political, and societal factors to trust systems. In Pakistan, there is a widespread notion that contraceptives techniques are heavily affected by religious beliefs. There are various points of view that may be found in the media and in common debates. In the presence of a wide variety of viewpoints, it seems necessary to perform empirical investigation to determine the truth.

The research focuses on resolving a critical question: Is there a link between religious academics and contraception? What is the general public's understanding of Islamic teachings on family planning in Pakistan? Advocating for contraception is becoming increasingly important as the need for reproductive health care rises. among the 1.9 billion Women of Reproductive Age group (15-49 years) worldwide in 2019, 1.1 billion have a need for family planning; of these, 842 million are using contraceptive methods, and 270 million have an unmet need for contraception (United Nations, Department of Economic and Social Affairs, Population Division, 2019; Kantorová, Wheldon, Ueffing, Dasgupta, 2020).

Despite dropping production rates in much of the globe, fast inhabitant's expansion remains a serious concern in most developing nations, where demands are vast and resources are short. Advocacy is a new and hectic job for various programs. Advocates must capture and maintain the concentration of crucial audiences through compelling ideas and continuous improvement. Experimental proof of the advantages of contraception assists leaders in justifying their support. Inhabitants and state benefit from prenatal care in a variety of ways. One of the most important are the following:

\section{1) Saving women's lives}

Preventing unwanted pregnancies might save $1 / 4^{\text {th }}$ of all sympathetic mortality in underdeveloped nations. Adopting contraception helps to avoid risky abortions to stop unexpected reproduction. It also permits female to stops births to their best reproductive years \& avoid having more children that is healthy for them.

\section{2) Saving children's lives}

Pregnant women separated by minimum 2 years help moms have stronger infants \& boost the odds of infant survival by about fifty percent. Inhibiting births to a female's optimal reproductive years also increases the likelihood of her children alive and being fit.

\section{3) Providing women extra choices}

Limiting their own fertility with the use of effective contraception can allow many women to pursue an education, a profession, and community participation. Mates with less children are also possible to send both their girls and boys to school.

\section{4) Benefits of Slower Population Growth}

Fertility declines and increment in inhabitants slows as more individuals choose family planning. Although reproduction has declined globally, additional drops would make a significant impact in various under-developed states. The global inhabitants have surpassed six billion people \& is increasing by over eighty million people every year. Retarded growth of population benefits progress by buying time \& 
providing a demographic bonus that can be invested in health care sector, education sector, job creation, and more measures to increase standards of living.

Poor awareness regarding the effect of long-term measures on production, along with a lack of comprehension of the operations, notably vasectomy, have fueled misconceptions and notions which impede the successful advertising and use of the facilities. According to untruth \& belief, Vasectomy is a same as Castration. Most Ugandan males and females believe that removal of the testicles is involved in vasectomy, making a male incapable to get an erection, and so stopping him from having more children.

Breast reduction is equivalent with castration because it renders the testicles, if present, incapable of conceiving, just as a man without testicles is incapable of conceiving. Another misconception and assumption is that a vasectomy results in the loss of manhood. Many attitudinal and cultural impediments remain in the way of long-term and permanent family planning approaches. Long-term and permanent procedures are influenced by attitudes that support big families and repeated childbirth.

According to Omran (1992), Family is the main social unit of society and Islamic civilization. Even in the absence of overwhelming population pressures, there has been concern about family planning and spacing. Over the years, the Islamic perspective on marriage, family formation, and child raising evolved and changed. Increment in inhabitants' rates in the Muslim world are influenced by a variety of variables.

Due to a lack of financial resources and the damaged nature of Middle Eastern countries, people employ children as the merely community protection approach, they can pay, they believe, even though the apparent counterargument. Women's vile status in religious-fundamentalist Muslim countries precludes female from acquiring an education \& excelling in professions, restricting their revitalized options, and boosting the required family sizes. Numerous devout Muslim Scholars oppose such family planning methods, as well as vasectomy and other kinds of contraception (Underwood, 2000). The collection of Islamic hermeneutic texts has a broader spectrum of academic viewpoints on family planning than is shown here. In terms of contraceptive method, Muslim academics unanimously accept the authenticity of a narrative. Several Qur'anic passages reinforce the idea that God does not want to burden followers, implying that the standard of children takes precedence over worries about numbers.

\section{Family Planning in Islamic Perspective}

The form of communication has long may be seen as critical authenticity of information. As we all know, a Muslim has three sources of knowledge to which he or she might seek solutions to questions regarding human being life guidance. These sources are discussed earlier in paper. Among the many perspectives of Muslim jurists, Imam Ghazali had a more extended stance in allowing contraceptive prevention. He recognized the following grounds for using contraception: a wish to maintain a female's beauty or health, or to protect her life, a want to prevent economic difficulties as well as mortification, and a desire to prevent other home troubles brought by a big family. He was vehemently opposed to the introduction of contraception, particularly to avert the birth of a female child. In addition to Al-developed Ghazali's viewpoint, several other religious scholars, such as Ibn-e-Maja along with Ahmad, believed that coitus interruptions were permissible by the Prophet (PBUH).

Al-Ghazali differentiated between infanticide and pill. He asserted an infant might not be made just by the emission of sperm, but by the settle down of sperm in the female's womb; because children were not made just by the male's sperm, but by the combined sperm of both parents. As a result, condom couldn't be equated to infanticide, which was the killing of an existing creature, but contraception was not. Two (male and female) emissions in the contraceptive process are equivalent to two aspects in Islamic law, 'offer' (ijab) and 'acknowledgement' (qabul) that are aspects of a business agreement.

Anyone who enters into a contract and then wants to withdraw it before the other party accepts it is not in violation of contract since a bargain does not exist until it is recognized. Similarly, there is no meaningful distinction in a man's ejection and retention of sperm until it really combines with a female's sperm. In the early fourteenth century, another prominent philosopher, Ibn Taymiyah, studied divine judgement, propagation, and condom (in this manner). "Allah makes children and other creatures in the womb by desiring the meeting of parents in intercourse, and the two semen in the womb," he claims. A 
fool says, 'I will rely on God and not approach my wife, and if it is willed that I be provided a kid, I will be permitted one, otherwise not, and there is no need for intercourse. 'This is fundamentally different from having intercourse and practising abstinence because withdrawal does not preclude pregnancy if God wills it, because there may be uncontrolled sperm pre-emission.' Ibn Taymiyah's formal name is Ibn Taymiyah. (Ibn Taymiyah, 1966).

\section{Status of Family Planning in Islam}

According to an examination of the literature, contraception is not stated in the Quran; nonetheless, Prophet Muhammad (PBUH) is said to have granted implicit consent for azl (coitus interruptus or withdrawal) in the Hadith. According to Hazrat Jabir, one of his friends, as recounted in Sahih Bukhari, we used to have recourse to azl during the days of the Prophet while the Quran was being revealed. He came to know of it but he did not prevent us from doing so".

\section{Barriers to Family Planning}

According to the final evaluation the major barriers to family planning are given below:

1. Cultural norms: More children, son preference etc.

2. Religious aspects

- Allah ki dainn hain bachay

- Allah rizq denay wala hai

3. Lack of awareness

4. Lack of access to contraceptives

5. Fear of side-effects

\section{CONCLUSION}

It is crucial to note that religion and contraceptives have not yet been a topic of discussion, either among thinkers and divine masters or in the holy sector. Religious kings, policymakers, and philosophers, failed to take responsibility for holding conversations or conversations on Islam and contraception, making it the most neglected issue. This circumstance aided in the establishment of misconceptions, misunderstandings, and a lack of interest on the part of stakeholders, resulting in misinformation on the subject, and it seemed a land of chatters and incorrect considerations from individuals who were not academics, religious leaders, or policymakers. Additionally, this perplexed mood leads to a communication schism among everybody.

\section{RECOMMENDATIONS}

- Religious leaders should discuss and debate contraceptive problems on television in order to reach a larger audience. Similarly, students at educational institutions should be educated about family planning methods.

- Religious leaders are the best advocates for contraception and religion for individuals lend an ear to them and media may be a useful vehicle for spreading the message. In Friday sermons, people can be informed about family planning issues, and family planning materials can be provided.

- Health professionals may play an important part in distributing the idea; to encourage them, their pay might be enhanced, and they might be taught Islamic FP principles. There should be instructive gatherings in the various areas.

- There should be separate state gatherings for male and female to discuss FP and associated topics. FP can be encouraged with the assistance of a Female Healthcare Professional, \& essential services can be offered at the patient's door. Educated ministry personnel may aid in the promotion of a policy initiatives. Females with little or no education may be barred from working as LHWs.

- In religious institutions, written materials and information on Islam \& FP should be available. 
- Islamic Scholars, political leaders, the media, \& health professionals may all work together to spread the word about FP. Actresses, and cricket celebrities may also be engaged in the lobbying initiatives to increase their impact.

- Many individuals are concerned that commercials should not be shown on television because they cause humiliation for the elderly. Instead, instructive seminars for men and women should be held individually at the community stage.

- Islamic Scholars should reach an agreement \& present information about FP in the context of Islamic teachings on television, and they should be persuaded to write pieces for newspapers. Local officials, such as Nazims, can be persuaded and involved in FP advocacy.

- To educate the general population, print materials on FP may be distributed in Mosques \& Madaris.

- Some members of the general population believe that the actual difficulties are religious Scholars who, if they come out in support of FP, would be followed by the community. Maulvis, their spouses, Pirs (spiritual leaders), teachers, physicians, and elderly ladies in the society are powerful members of the society, and people believe and obey them.

\section{REFERENCES}

Butler, A. S., Clayton, E. W., eds. (2009). Overview of Family Planning in the United States. National Academies Press (US).

Corsa, L. Jr. (1965). Family planning in Pakistan. American Journal of Public Health, 55()3, 400-403.

Kantorová V., Wheldon, M.C., Ueffing, P., \& Dasgupta, A. N. Z. (2020) Estimating progress towards meeting women's contraceptive needs in 185 countries: A Bayesian hierarchical modelling study. PLoS Med, 17(2):e1003026. https://journals.plos.org/plosmedicine/article?id=10.1371/journal.pmed.1003026

Omran, A. R. (1992). Family planning in the legacy of Islam. London and New York: Routledge.

Underwood, C. (2000). Islamic precepts and family planning: The perceptions of Jordanian religious leaders and their constituents. International Family Planning Perspective, 26(3), 110-136.

UNFPA (1994). International Conference on Population and Development (ICPD), 3-13 September. Cairo, Egypt: UNFPA. https://www.unfpa.org/events/international-conference-population-anddevelopment-icpd

United Nations, Department of Economic and Social Affairs, Population Division (2019). Family Planning and the 2030 Agenda for Sustainable Development. New York: United Nations. https://www.un.org/en/development/desa/population/publications/pdf/family/familyPlanning_Dat aBooklet_2019.pdf

World Population Review (2021). Pakistan Population 2021 (live). Retrieved from https://worldpopulationreview.com/countries/pakistan-population on 12th August 2021. 